\title{
Socio-economic challenges to work-life balance at times of crisis
}

\author{
Roberta Guerrina \\ r.guerrina@surrey.ac.uk
}

Paper to published on the Journal of Social Welfare and Family Law (DOI:
10.1080/09649069.2015.10181223)

Abstract

It is now well established that work life balance should not only be regarded as a fundamental employment right, but also as an important element for the achievement of other EU policies and is key to promote women's activation in the labour market. For this purpose, European institutions (namely the Commission and the European Parliament) set about implanting a set of policies and legislative measures between the late 1990s and 2008. The onset of the sovereign debt crisis in 2008 and the associated austerity measures have posed a serious challenged to realisation of the Lisbon Agenda to establish a comprehensive framework for the reconciliation of work and family life. Crisis has provided an opportunity for ideologically driven cuts aimed at retrenching the Europe social model. The debates at the national and European level seemingly ignored the gendered nature of this policy shift, thus reasserting the centrality of hegemonic gender norms across Europe. This article seeks to assess the extent of the impact of the recession and of the austerity measure that were introduced as a mean to address the challenges of economic crisis on work life balance policies.

\section{Introduction}

The European Union's commitment to equality between men and women has become one of the most important foundational narratives of this organisation (MacRae, 2010). European institutions' contribution to the development of a comprehensive framework for equality in the area of employment led Walby (2004) to conclude that it is a gender regime in its own right. Work-life balance and reconciliation policies developed in the 1990s and 2000s were seen by many as the "holy-grail" in the quest for substantive equality (Guerrina 2005). The onset of the crisis, however, has significant implications for social inclusion and gender equality in Europe. Despite the emergence of counter narratives that point to the unintended consequences of austerity, political commentators have largely ignored the gender question in their analysis of the Eurocrisis (Annesley and Himmelweit 2010, European Women's Lobby, 2012, Women's Budget Group 2011). 
This article looks at the impact of the crisis on initiatives aimed at supporting women's access to the labour market. In this respect, it starts from the assumption that economic crises, and associated government responses, are deeply gendered. It therefore seeks to assess the extent to which austerity has undermined work-life balance policies in Europe. In particular, it looks to establish whether the economic crisis has had an impact on European institutions' commitment to the reconciliation agenda that defined much of their work and was consolidated in the Lisbon Strategy 2000 (European Council 2000) and the European Council Integrated Guidelines (2005) for increasing women's total share of the employment market (European Commission 2005, European Council 2000).

This article will provide an overview of the impact of the crisis on achieving the ambitions of the reconciliation agenda. Specifically, it will start by outlining how and whether economic crises are gendered. This analysis will assess the impact of gender ideologies on shaping institutional approaches to the crisis. Assumptions about which services are core and which ones can be cut at times of financial crisis is based on assumptions about the role of the state as a provider of social welfare. Gender divisions of labour in the private sphere, however, determine who is available to step in and fulfil those functions. It therefore follows that reconciliation policies, primarily aimed at women's activation, are likely to become dispensable in the context of crisis, as they are likely to be seen as expensive "luxuries". This will in turn provide important insights into the resilience of women's participation in the labour market.

\section{The Context: Gendering austerity}

This article supports wider arguments about how austerity has served to reinstate a socially conservative gender ideology that challenges the newly established adult worker model (Karamessini 2014, Walby 2009). From this perspective, the deeply gendered nature of austerity politics and associated policy agenda, have led to a retrenchment of equality and social justice as policy priorities. The widespread impact of Europe wide cuts on working women/mothers could and should have been predicted - for instance by carrying out gender impact assessments - but a detailed analysis of the cost of inequality has been largely superseded by what are deemed to be "higher" political priorities. Ultimately, this article reveals that behind a veneer of 
neutrality, reconciliation policies' focus on enabling women's access to employment in the official labour market allowed for the marginalisation of this policy area during the crisis. Widespread national welfare cuts coupled with re-emerging social conservatism, lack of affordable childcare provisions, and a popular press that largely opposes maternal employment are penalising women/mothers engaged in the official labour market (Anon 2008; Associated Press 2014). The data on maternal underemployment is particularly worrying as it crystallises gendered norms of dominant economic structures and discourses (Eurostat 2015, Eurostat 2014).

The highly volatile nature of the European economic climate over the last five years has led an increasing number of states to take drastic measures to cut government spending in an attempt to curb the sovereign debt crisis. The perceived nature of the current crisis has led most European governments to adopt increasingly draconian measures justified by the exceptional nature of recent and unfolding events. The financial viability of hard won rights, such as maternity leave, is starting to be challenged (Rock \& Boffey 2011). The political economy of austerity is thus not just gendered, it is actively undermining core arguments about the economic value of equality, to say nothing of gender justice.

The current environment is particularly concerning in relation to the position of working mothers. The International Labour Organisation (2012) reported on the impact of austerity on the public sector in Europe, highlighting how the cuts have inevitably had a detrimental impact on women's employment rates. Moreover, working mothers are identified as a category of workers particularly badly affected by these policies. Considering that historically the public sector has played a key role in providing employment for women and, as a group, they are highly dependent on public services in order to participate in the labour market, it follows that changes in public sector funding will affect women's ability to participate in paid work both as employees and as consumers of services (International Labour Organisation 2012; Rubery 2014).

\section{Ideological contestations: reconciliation policies in the context of austerity}

It is now well established that work life balance should not only be regarded as key to achieving women's labour labour market activation For this purpose, it is 
acknowledged that between the 1990s and 2008 a set of policies and legislative measures aimed at enabling work- life balance has been steadily implemented (Gregory \& Milner 2009; Gregory et al. 2013). The onset of the sovereign debt crisis in 2008 and the associated austerity measures provided an opportunity for ideologically driven cuts aimed at retrenching the welfare state across Europe. Benefits directly targeting women's access to the employment market have been amongst the first to be cut, justified on the basis that the family was going to be required to take on a greater role in delivering welfare provisions. The debates at the national and European level seemingly ignored the gendered nature of this policy shift, thus reasserting the centrality of hegemonic gender norms across Europe (Karamessini \& Rubery 2014).

Understanding the interaction between mothering, caring and division of labour is key in the analysis of gender regimes. The transition from the male breadwinner model to the adult worker model has been predicated on a shift in employment-care balance. Much of the published work on gender models and women's employment has tried to come to terms with how socio-economic structures accommodate women's participation in the official labour market. Activation policies that sought to increase women's opportunities for engaging with paid employment were seen as key to challenge gender hierarchies in the private sphere (Annesley 2007; Lewis 2001; Warren 2007). At the heart of this discussion are questions relating to ideologies of gender, which ultimately rest upon assumptions about the relationship between mothering, caring, paid work/employment and the state.

Within this wider socio-cultural and political context, maternal activation has been framed as a tool in the hands of policy makers for the resolution of higher political priorities, such as skills shortages and demographic transitions (e,g. ageing population). This functional approach to women's activation and equality of opportunities is indicative of a failure of mainstreaming to generate a genuine commitment to substantive equality and challenging hegemonic gender norms. The context of the cuts and austerity should therefore not be seen as a paradigm shift in policy direction, but merely as a platform for the legitimisation of a gender ideologies based on traditional power hierarchies. 
At a superficial level, this increase in social conservatism appears to contradict arguments about the emergence of the adult worker model. A more detailed assessment of the concept of breadwinner highlights the need for continued feminist contestation of mothering as a social function used to support the state and associated socio-economic agendas. Although there is no accepted definition of breadwinner/breadwinning in the literature, a number of common assumptions about divisions of care work underpin these definitions (Warren 2007). It is my contention that debates about the future of the adult worker model and the changing nature of breadwinning structures are premised on gender ideologies about mothering. It is the values that underpin these ideological frameworks that are used to justify shift in policy at times of crisis.

It is worth going over the core assumptions that can be deployed to justify a shift in policy focus and trajectory in the context of austerity that support traditional gender norms and would therefore work against women's activation in labour market. First of all, it is important to note that this is a highly contentious issue as it brings the family into the political sphere making it the subject of debate and policy action. Secondly, it challenges deeply rooted beliefs about gender structures and divisions of labour. Finally, it raises important questions about social norms and change. Ultimately, the way that the media chooses to report these stories shapes our understanding of women's role in society and so the "mother war" goes on.

\section{Gender, Integration and Governance: a complex and uneasy relationships}

Undoubtedly, the EU has been a positive force in promoting women's employment rights. Walby (2004) went as far as defining it a gender regime and a gender actor. Looking at how the principle of equality has developed over the last 50plus years of European integration provides useful insights into the opportunities and pitfalls of an approach to equality that is essentially premised on the acceptance of the neo-liberal paradigm. It has provided a safety net that safeguards women's access and position in the official labour market. It is important to recognise the achievements of this organisation, and many of the people working within its institutions, in promoting a women friendly policy agenda. 
The achievements of the last fifty years should not be taken for granted. The Eurocrisis and associated politics of austerity highlight the fragile nature of these gains. Austerity is a deeply gendered approach to crisis management. Many of the cuts enacted by European governments over the last few years affect social and welfare services that often enable women to participate in the official labour market. The discourse of crisis is increasingly seen as in conflict with the rights and social cohesion agenda. Part of the problem is that many of the (hard won) rights now entrenched within European and national law focus on promoting a framework for access to the labour market. At these particularly difficult economic times, it is therefore all the more important that European institutions hold the ground on gender equality, even if their stance is biased in favour of formal (rather than substantive) equality.

The EU has been a key actor in promoting women's role in the official labour market. A number of scholars have evaluated strengths and weaknesses of the European gender regime (see for instance, Beveridge \& Velluti 2008, Guerrina 2005, Hoskyns 2004, Kantola 2010, Walby 2009). In particular, reconciliation policies have been interrogated for their potential impact on traditional divisions of labour. Jane Lewis (2006) has argued that in order to understand the intended and unintended consequences of social policies in shaping gender hierarchies we have to understand how these policies are framed. Equal opportunity policies are one of the most widely developed area of EU social policy action, however, for Lewis (2006) 'it is difficult to find evidence to support its independent existence' (p.424). The history of the European equality agenda points to a functional logic that justified its development (Guerrina 2005, Kantola 2010, Lewis 2006). At the point that the principle of equal pay was introduced in the Treaty of Rome to avoid social dumping, a degree of path dependency defined the ensuing development and Europeanisation of equal opportunities policies. The ideologically bounded way in which the principle came to be included in the process limited the scope of the policies and defined the highly commodified nature of the European gender regime.

In the same way that equality of opportunities was introduced to ensure fair competition in the Single Market, so reconciliation policies served a higher policy agenda, e.g. as a way of tacking concerns about declining birth rates and ageing 
population (Guerrina 2008). The overlapping discourses of activation and competitiveness underpin this process. Much of the work on women's employment rights and European social policy highlights how it is economic imperatives, rather than the logic of social justice, that underpin many of the developments in the policy field.

The focus on activation and participation in the labour market as a vehicle for equality throughout the 1990s and early 2000s, however, masks wider social inequalities. As long as equality is framed in terms of economic gains and market competitiveness it will remain at the service of higher economic and political imperatives. The additional challenge posed by demographic trends, adds a sense of urgency to the need to address the structural impediments to women's activation, rather than the root causes underpinning the individual choices about family structures. 'To the extent that these matters are discussed, they are framed no longer as a matter of equality policy but as a matter of active labour market policy or an effort to "render the family more "employment-friendly"' (Locher and Prugl 2008, p.9). The failure of repeated policy initiatives (COM (2008) 635 Final) to address the work-care binary ultimately highlights an additional tension; whereas the principle of equality provides the legitimizing logic for this policy agenda, economic imperatives remain the main drivers for its implementation.

Using the frame of "gender policies", as opposed to "women's policies" or "feminist policies", Kantola (2010, p. 105) looks at the impact of the reconciliation agenda on dominant hierarchies of power. Her analysis of reconciliation policies provides a warning to policy engaged scholars and activists who have used economic arguments in support of widening the scope of this policy area. As she explains,

This is a familiar trends and debate in the EU where social policy is often justified in terms of its benefits for the dominant economic growth and competition agenda. Women, in particular, become an 'untapped labour reserve' where women's labour market participation is seen as a means to increase competitiveness and the tax base of European welfare states (Kantola 2010, p.106)

Clearly, this is a strategic approach deployed to engender support amongst various economic interests for what is often seen as a costly area of intervention. This proved 
to be a successful strategy in the first decade of the $21^{\text {st }}$ century. Supported by increasing concern over European demographic trends, reconciliation and women's activation were seen as key to the long-term success of the Single Market (Guerrina 2008, Villa and Smith 2013).

The recent financial crisis, however, caused a paradigm shift in European rhetoric. Legitimacy for the process of European integration is no longer derived from promoting social and economic cohesion, but from financial stability. Changing policy priorities and increasing focus on the long term success of fiscal and monetary objectives have led to a decline in interest in demographic trends, women's activation and equality. This highlights the inherent danger of the strategy adopted by the Commission for promoting equality. At the point at which equality no longer benefits higher economic priorities, it becomes acceptable collateral damage. This is where the political economy of austerity will prove to be a critical juncture for substantive equality in Europe.

\section{Promoting the Adult Worker Model in Europe: Challenging the dominant gender order?}

The European Union has been a key actor in promoting women's role in the official labour market. In relation to the position of mothers, the European Commission was responsible for instigating a debate about equality and health and safety. The ratification of the 1992 Pregnant Workers Directive (ADD Reference) is a critical juncture in the development of an integrated approach to family friendly policies in Europe. Despite significant opposition from member states governments, the Directive was ratified as a health and safety measure to provide a minimum safety net across the Single Market (Beveridge 2008; Guerrina 2005). The EU's bias for social and economic policies that enable the functioning of the Single Market ultimately provides an overarching framework for handling women's contributions to the process of European integration. What emerges is a deeply commodified understanding of mothering that is consistent with the overall ethos of the organisation. 
This provides important insights into the core objectives that define the thrust of the policy. In the case of working mothers, it is therefore important to differentiate between policies framed within the context of health and safety, and those pertaining to equality of opportunities or reconciliation. Each frame defines a different discourse, it supports power structures and defines opportunities and constraints.

The backdrop for the development of a comprehensive reconciliation agenda is the Lisbon strategy (European Council 2000) in the first instance and Europe 2020 (European Commission 2010) more recently. The overlapping discourses of activation and competitiveness underpin this process. In the context of Lisbon, increasing women's employment rates - to reach $60 \%$ of the population - is seen as key to increase the competitiveness of the European labour market. It will also allow policy makers to address concerns about labour shortages likely to result from an ageing population and decreasing birth rates (Guerrina 2008).

Implicit within the Lisbon Agenda are measures aimed at increasing maternal participation in the official labour market. The 2002 Barcelona childcare targets thus seek to improve both the availability of affordable and good quality childcare. These targets are now integral parts of the European Employment Strategy (EES) and the Lisbon strategy (European Council, 2000) and the European Commission (2008) communication on work life balance (COM(2008)635 Final). Garofalo and Marra (2007) point to the balance between quantitative measures for the improvement of women's employment opportunities (see table below) and qualitative measures, focused on structures and opportunities. For them the key innovation consisted in linking employment targets to development targets, and in supporting an integrated approach to those policies that contributed to improving the standard of living, and, ex ante, the opportunities of choice for people overall, as well as from an egalitarian perspective (Garofalo \& Marra 2008, p. 3).

\begin{tabular}{|l|l|l|}
\hline Policy & Objectives & Activation measures \\
\hline Lisbon Agenda & $60 \%$ Female employment & \\
\hline Barcelona Targets & & $90 \%$ children aged 3 to \\
\hline
\end{tabular}




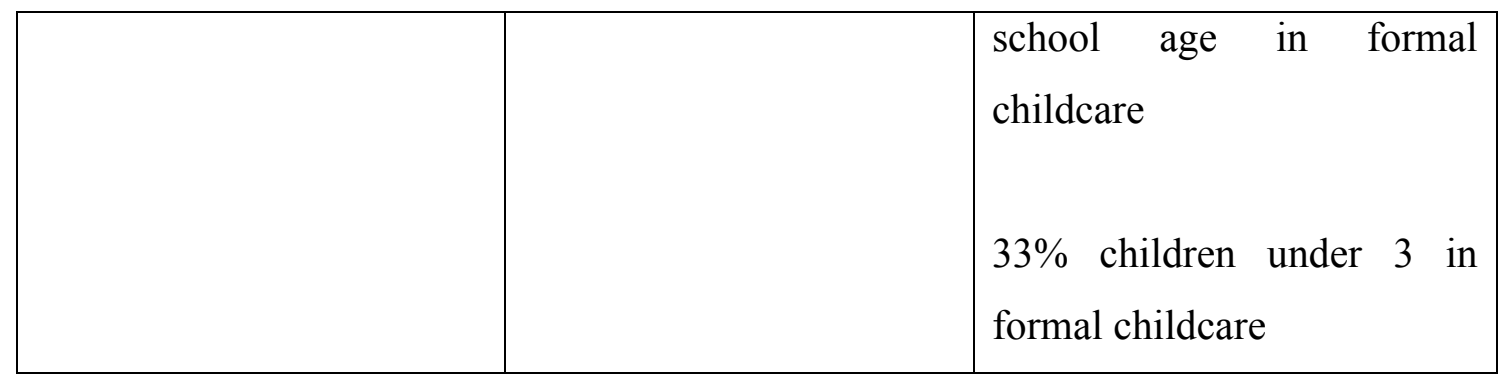

Table 1: Lisbon Agenda/EES targets and activation measures

Garofalo and Marra (2007) seek to untangle the relationship between paid and care work as understood through the prism of de-commodification. They seek to challenge the assumption that an increase in women's (i.e. working mothers) participation in the labour market has to lead to greater marketisation of care functions.

The work-life reconciliation policy approach consists then of providing financial resources, technical assistance, and services in kind to both individuals and households. The aim is to fill the specifically diagnosed socioeconomic or psychological gap, which would hinder the attainment of the socially desirable balance between production and social reproduction (Garofalo and Marra 2007, p. 14).

Their analysis seeks to account for cognitive and affective variables shaping women's choices (whether real or presumed) about care and paid work. This analysis leads them to a potentially surprising conclusion: reconciliation policies engender conflict within the family due to the constant negotiation for finding a balance between responsibilities entrenched within both roles (caring and employment) (Garofalo and Marra, 2007).

The main problem identified by much of the literature relates to the language of reconciliation. Largely presented in gender neutral terms, policies aimed at increasing work-life balance are directly aimed at women/working mothers. The drivers for the policies, i.e. competitiveness and demographic renewal, further highlight the economic imperatives of European social policy and gender politics. Garofalo and Marra (2007, p.18) point out the idiosyncratic nature of this policy agenda that does not, and cannot, change patterns of unpaid care work in the private sphere, as long as gender divisions remain unaltered. The impact of this shift is clear when unpacked through the lenses of the breadwinner model: “the hours of women's work remain unspecified, and in many Western European countries a modified male breadwinner 
model - that is, a one-and-a-half-earner model - has become the norm" (Lewis 2006, pp.425-6). This is a shift in terms of employment patterns, but not a change in terms of the power hierarchies that arise from the unequal distribution of paid and unpaid work in the family unit.

The focus on activation and participation in the labour market as a vehicle for equality throughout the 1990s and early 2000s, however, masks wider social inequalities. As long as equality is framed in terms of economic gains and market competitiveness it will remain at the service of higher economic and political imperatives. The additional challenge posed by demographic trends, adds a sense of urgency to address the structural impediments to women's activation, rather than the root causes underpinning individual choices about family structures. As Locher and Prugl (2008) explain, 'To the extent that these matters are discussed, they are framed no longer as a matter of equality policy but as a matter of active labour market policy or an effort to “render the family more 'employment-friendly' (p.9) The failure of repeated policy initiatives (COM (2008) 635 Final) to address the work-care binary ultimately highlights that equality provides the rhetoric for this policy agenda, but economics provides the imperatives for its implementation. Prugl and Locher (2008) draw attention to the shift in the dominant policy discourse: from sharing of family responsibilities/care to facilitating women's entry in the official labour market The shift supports a move towards an adult worker or dual breadwinner model which does not substantially challenge the traditional gender order.

Europe 2020 was launched in 2010 to promote sustainable growth in Europe. Building on the European Employment Strategy, this programme for enhancing growth and social inclusion was launched soon after the onset of the Euro-crisis. It is a comprehensive strategy that includes European and national targets relating to employment, education, energy efficiency/emissions and social inclusion. What matters for the purpose of this article is the target of $75 \%$ employment for working age population. Having achieved the Lisbon target of $60 \%$ employment for women, they are largely overlooked as a target group by this initiative. In relation to promoting women's employment, Europe 2020 recognizes that although previous initiatives (e.g. the EES) have succeed in increasing women's participation in the labour market, it is still significantly lower than men's (European Commission, 2010). 
It is interesting to note that although women appear as target group for activation policies, the focus of the strategy moves away from addressing structural barriers to women's labour market participation. No mention is made of the impact of austerity on the provision of key services that enable women to reconcile work and family life (European Commission 2014).

The European Commission's (2014) own assessment of its progress at the mid-way point of this programme highlights the impact of the crisis on meeting the employment targets. What is important to note is that any analysis of women's employment is missing altogether from the Report. This silence is significant as it highlights the impact of the crisis on long standing commitments by the EU for women's activation. Ultimately, this is a change from the Commission's focus over the last twenty years, whereby women's activation now appears to be less of a priority as it seeks to put in place measures to stabilize the overall employment rate in Europe (European Commission 2014).

The narrative of crisis has made it easier to shift the policy focus from reconciliation and high quality employment for women to total employment figures. The Commission's Experts Report (Bettio et al., 2012) highlights the impact of the crisis on un-paid work. The report specifically highlights how the crisis generated a backward step in gender divisions of labour in relation to care and family responsibilities:

Overall, these findings offer some evidence that the gender gap in the allocation of unpaid work may have widened during the recession in countries where disparities in housework and care between men and women are especially pronounced (Bettio et al. 2012)

Retrenchment in the provision of key services (e.g. childcare) that facilitate women's participation in the official labour market has been one of the main outcomes of austerity politics in Europe over the last seven years. Pushback towards women fulfilling the social function of care in the private sphere and an accentuation of the double burden are some of the most significant outcomes of the crisis (European Women's Lobby, 2012). This is likely to undermine progress towards substantive equality enabled by the development of a comprehensive framework for reconciliation between work and family life in the 1990s and 2000s. 


\section{Conclusions}

The financial crisis of the last five years caused a paradigm shift in European rhetoric. Changing policy priorities and increasing focus on the long term success of the Single Currency have led to a decline in interest in demographic trends, women's activation and equality. This highlights the inherent danger of the strategy adopted by the Commission for promoting equality. At the point at which equality no longer benefits higher economic priorities, it becomes acceptable collateral damage. This is where the political economy of austerity will prove to be a critical juncture for substantive equality in Europe.

What emerges from the analysis presented above is that policies for reconciliation between work and family life, and by extension working mothers, have fallen victim to higher political and economic priorities. In a way political discourse has made working mothers acceptable collateral damage, particularly as falling back into traditional gender structures and divisions of labour allows governments to carry out substantial cuts to social and welfare services. What seems clear is that European governments have capitalised on women's roles in the private sphere to push through a comprehensive reform agenda of the European social model. 


\section{Bibliography}

Annesley, C., 2007. Lisbon and social Europe: towards a European "adult worker model” welfare system. Journal of European Social Policy, 17,(3), 195-205. doi:10.1177/0958928707078363

Annesley, C., and Himmelweit, S., 2010. The Impact on Women of the Coalition Spending Review 2010. UK Women Budget Group, London.

Anon., 2008, August 6. "Excessively Hard-Working Families." The Independent. Retrieved from http:// www.independent.co.uk

Associated Press., 2014, August 12. 40 \% of managers avoid hiring younger women to get around maternity leave. Retrieved from http://www.theguardian.com/money/2014/aug/12/managers-avoid-hiringyounger-women-maternity-leave\#comments

Bettio, F., Corsi, M., D’Ippoliti, C., Antigone, L., Samke Lodovici, M., and Verashchagina, A., 2012. The impact of the economic crisis on the situation of women and men and on gender equality policies. European Commission, DGJustice. Publication Office of the EU, Luxembourg doi:10.2838/481

Beveridge, F., 2008. Implementing Gender Equality and Mainstreaing in an Enlarged European Union: Prospects and Challenges. In F. Beveridge \& S. Velluti (Eds.), Gender and the open Method of Coordination: Perspectives on Law, Governance and Equality in the EU. Aldershot : Ashgate, 11-34.

Beveridge, F., \& Velluti, S. (2008). Gender and the Open Method of Cooperation: Perspectives on Law, Governance and Equality in the EU. Aldershot:Ashgate.

European Commission. (2005). Communication "Working together for growth and jobs. A new start for the Lisbon strategy". $\operatorname{COM(2005)~} 24$ final.

European Commission, 2008. Communication from the Commission to the European Parliament, the Council, The European Economic and Social Committee and the 
Committee of the Regions, A Better Work-Life Balance: Stronger Support for Reconciling Professional, Private and Family Life. COM(2008)635Final

European Commission, 2010. Europe 2020: A Strategy for Smart, Sustainable and Inclusive Growth, COM(2010)2020 Final (2010). Retrieved from http://eurlex.europa.eu/LexUriServ/LexUriServ.do?uri=COM:2010:2020:FIN:EN:PDF

European Commission, 2014. Taking stock of the Europe 2020 strategy for smart, sustainable and inclusive growth COM (2014) 130 Final/2.

European Council, 2000. Lisbon European Council 23 And 24 March 2000

Presidency Conclusions . Retrieved from

http://www.europarl.europa.eu/summits/lis1_en.htm

European Council, Decision of 12 July 2005 on Guidelines for the employment policies of the Member States (2005/600/EC) (2005).

European Women's Lobby, 2012. The price of austerity - The impact on women 's rights and gender equality in Europe. Retrieved fromEuropean Womens Lobby http://www.womenlobby.org

Eurostat, 2015. Underemployment and Potential Additional Labour Force Statistics. Available at: http://ec.europa.eu/eurostat/statisticsexplained/index.php/Underemployment_and_potential_additional_labour_force statistics\#Further_Eurostat_information

Eurostat, 2014. Europe 2020 Indicators - Employment. Available at: http://ec.europa.eu/eurostat/statisticsexplained/index.php/Europe_2020_indicators_-_employment

Garofalo, M. R., and Marra, M., 2007. Work-Life Reconciliation Politics From WellBeing to Development: Rethinking EU Gender Mainstreaming. MPRA Paper, No. 9598. Retrieved from http://mpra.ub.uni-muenchen.de/9598 
Gregory, A., and Milner, S., 2009. Editorial: Work-life Balance: A Matter of Choice?

Gender, Work \& Organization, 16,(1), 1-13. doi:10.1111/j.1468-

0432.2008.00429.x

Gregory, A., Milner, S., Windebank, J., Eikhof, D. R., Warhurst, C., and Haunschild, A., 2013. Work-life balance in times of economic crisis and austerity.

International Journal of Sociology and Social Policy, 33,(9/10), 528-541.

doi:10.1108/IJSSP-05-2013-0061

Guerrina, R., 2005. Mothering the Union: Gender Politics in the EU. Manchester : Manchester University Press.

Guerrina, R., 2008. Employment policy, women's labour market activation and demographic trends. In F. Beveridge \& S. Velluti (Eds.), Gender and the Open Method of Coordination: Perspectives on Law, Governance and Equality in the EU. Albingdon: Routledge, 35-54.

Hoskyns, C., 2004. Gender Approaches. In A. Wiener \& T. Diez (Eds.), European Integration Theories. Oxford : Oxford University Press.

International Labour Organisation, 2012. Women in EU public sector face higher risk of losing jobs. Retrieved from http://www.ilo.org/global/about-theilo/newsroom/news/WCMS_186147/lang--en/index.htm

Kantola, J., 2010. Gender and the European Union. Basingstoke: Palgrave MacMillan.

Karamessini, M. (2014). Women's Vulnerability to Recession and Austerity: A Different Crisis, A Different Context. In M. Karamessini \& J. Rubery (Eds.), Women and Austerity: The Economic Crisis and the Future for Gender Equality. Abingdon: Routledge (Kindle Edition)

Karamessini, M., and Rubery, J. (2014). Women and Austerity: The Economic Crisis and the Future for Gender Equality. Abingdon:Routledge (Kindle Edition) 
Lewis, J., 2001. The Decline of the Male Breadwinner Model: Implications for Work and Care. Social Politics: International Studies in Gender, State \& Society, 8,(2), 152-169. doi:10.1093/sp/8.2.152

Lewis, J., 2006. Work / family reconciliation, equal opportunities and social policies : the interpretation of policy trajectories at the EU level and the meaning of gender equality. Journal of European Public Policy, (April), 420-437.

Locher, B., and Prugl, E., 2008. Gender and European Integration. ConWEB, (2). Retrieved from www.bath.ac.uk/esml/conWEB

MacRae, H., 2010. The EU as a Gender Equal Polity : Myths and Realities. Journal of Common Market Studies, 48,(1), 155-174.

Rock, L., and Boffey, D., 2011, July 30. Coalition Cuts are Making life tough for mothers". The Observer.

Rubery, J., 2014. From "Women and Recession" to "Women and Austerity": A Framework for Analysis. In M. Karamessini \& J. Rubery (Eds.), Women and Austerity: The Economic Crisis and the Future for Gender Equality.pp. ? Abingdon: Routledge.

Villa, P., and Smith, M., 2013. Policy in the time of crisis: employment policy and gender equality in Europe. In J. Rubery \& M. Karamessini (Eds.), Women and Austerity: The eEconomic Crisis and the Future for gender equality. Abingdon: Routledge.

Walby, S., 2004. The European Union and Gender Equality: Emergent Varieties of Gender Regime. Social Politics: International Studies in Gender, State \& Society, 11,(1), 4-29. doi:10.1093/sp/jxh024

Walby, S., 2009. Gender and the Financial Crisis. Retrieved from www.lancs.ac.uk/fass/doc_library/sociology/Gender_and_financial_crisis_Sylvia Walby.pdf 
Warren, T., 2007. Conceptualizing breadwinning work. Work, Employment \& Society, 21,(2), 317-336. doi:10.1177/0950017007076642

Williams, F., 2009. Claiming and Framing in the Making of Care Policies: The Recognition and Redistribution of Care. UNRISD Papers, available at: http://www.unrisd.org/ [last accessed Sept 2009]

Women's Budget Group. (2011). The Impact on Women of the Budget 2011 UK Women's Budget Group - April 2011, (April),? 1-29. Retrieved from Women's Budget Group http:// www.wbg.org.uk 